\title{
Judicial RetiRements AND the STAYing Power of U.S. Supreme Court Decisions
}

\author{
Stuart Minor Benjamin and Georg Vanberg*
}

\begin{abstract}
The influence of U.S. Supreme Court majority opinions depends critically on how these opinions are received and treated by lower courts, which decide the vast majority of legal disputes. We argue that the retirement of Justices on the Supreme Court serves as a simple heuristic device for lower court judges in deciding how much deference to show to Supreme Court precedent. Using a unique dataset of the treatment of all Supreme Court majority opinions in the courts of appeals from 1953 to 2012, we find that negative treatments of Supreme Court opinions increase, and positive treatments decrease, as the Justices who supported a decision retire from the Court. Importantly, this effect exists over and above the impact of retirements on the ideological makeup of the Supreme Court.
\end{abstract}

\section{INTRODUCTION}

Opinions by the U.S. Supreme Court fundamentally shape the legal landscape and thus have a significant effect on social, economic, and political outcomes. As scholars have long recognized, much of this impact is realized indirectly through the manner in which high court decisions (which are relatively few in number) guide and constrain the decisions of other courts in the judicial hierarchy (e.g., Cameron Segal, and Songer 2000). Put differently, the influence and importance of any given Supreme Court decision is largely a function of its treatment in lower courts. Do lower court judges faithfully follow the opinion, ignore it, or perhaps cast doubt on it? Given that the manner in which Supreme Court decisions fare in the lower courts is so central, it is not surprising that scholars have taken great interest in understanding what drives lower court treatments of Supreme Court precedents. A rich literature, much of it developed over the last fifteen years, has illuminated this question. Thus, we now have a good understanding of how the characteristics of Supreme Court opinions - including the number of concurrences, as well as the size and breadth of the majority coalition - shape subsequent lower court treatment (Benesh and Reddick 2002; Benjamin and Desmarais 2012; Black and Spriggs 2008; Corley

\footnotetext{
* Benjamin is the Douglas B. Maggs Professor of Law, Duke Law School (benjamin@law.duke.edu); Vanberg is a Professor, Department of Political Science, Duke University (georg.vanberg@duke.edu). Thanks to Tim Calloway, Sean Chen, and Doug VanDerwerken for tremendous assistance in creating the dataset, Jane Bahnson, Brittany Edwards-Franklin, Andrew Jennings, Kelly Leong, Cassidy Nolan, and Benjamin Oster for valuable research assistance, and Jack Knight and Mat McCubbins for useful comments.
} 
2009). Similarly, scholars have made significant progress in uncovering how dynamic changes in the legal environment, including the age of Supreme Court opinions, and ideological shifts between the enacting and subsequent Supreme Courts, affect how lower courts treat precedents (e.g., Westerland et al. 2010, Hansford and Spriggs 2006).

In this paper, we focus on a factor that has escaped systematic analysis: The impact of personnel change on the Supreme Court over and above the impact of such change on the ideological composition of the Court. Specifically, we argue that - separate from the impact of judicial turnover on the general ideological position of the Court - the retirement of Supreme Court Justices who joined a majority opinion significantly impacts the staying power of the decisions they supported: As departures reduce the number of Justices on the Court who explicitly signed on to an opinion, lower court judges become significantly less likely to follow the opinion, and more likely to openly cast doubt on it. We argue that this effect results from the fact that judges on lower courts confront a complex task in applying a large number of potentially relevant precedents to the cases before them. As they do so, one key concern is to avoid censure by the current Supreme Court. In navigating this problem, lower court judges have strong incentives to look for simple heuristics that can help them to identify decisions that are more likely to have the support of the current Court (and should therefore be treated positively) and those less likely to enjoy such support (and can therefore be narrowly interpreted or ignored with less peril). While there are numerous such markers (many of which we control for in the empirical analysis below), the retirement of Justices who joined a decision constitutes a particularly prominent one that is easy to spot. A dwindling number of Justices who explicitly signed on to an opinion readily suggests that the opinion may enjoy less support on the current Court.

In focusing on this effect of judicial retirements, we highlight an aspect of change in the Court's membership that has received scant attention. Most analyses of turnover on the Court are concerned with the way in which such changes shift the Court's ideology (e.g., Ruckman 1993, Shipan and Shannon 2003), and what the impact on future Supreme Court decisions is likely to be (e.g. Baum 1992, Segal 1985). ${ }^{1}$ Our findings suggest that the effects of turnover on the

\footnotetext{
${ }^{1}$ Legal scholars and social scientists have made considerable progress in understanding the appointment process and exploring how ideological shifts on the Supreme Court affect future Supreme Court decisions. One important question in the literature concerns whether appointments will influence future decisions only when they "move the median" (Moraski and Shipan 1990) or whether appointments can have a significant impact even if they do
} 
Supreme Court go well beyond how the Court decides future cases. Retirements also shape the manner in which appeals courts implement existing precedents. Because these courts resolve the vast bulk of cases, this implies that the impact of judicial turnover on our legal system is potentially far greater than has traditionally been recognized. Justices may think of themselves as creating precedents that will long outlive them, but their opinions may instead diminish in importance as the Justices who supported them leave the Court.

The remainder of the paper is organized as follows. Part II explains why departures of Supreme Court Justices are likely to affect how appeals courts treat past Supreme Court decisions. Part III turns to a unique dataset that traces the treatment of all Supreme Court majority opinions by courts of appeals on a yearly basis from 1953 to 2012. These data allow us to investigate whether appeals court judges respond systematically to the retirement of Supreme Court Justices in their treatment of Supreme Court opinions. In Part IV we find strong evidence that, controlling for a wide variety of factors known to affect the treatment of Supreme Court precedent (including the general ideological shift of the Supreme Court), the retirement of Justices who supported an opinion significantly shapes the manner in which these opinions are treated subsequently: Opinions experience a significant decrease in influence as fewer and fewer of the Justices who originally joined an opinion remain on the contemporary Supreme Court. In Part V we conclude by discussing the ramifications of our findings for our understanding of Supreme Court precedents and the Supreme Court as a continuing body.

\section{SUPREME COURT RETIREMENTS AND THE TREATMENT OF OPINIONS}

In the American legal system, lower courts play a critical role - indeed, the vast majority of legal disputes are resolved in the lower courts, and never reach the Supreme Court. Lower federal courts handle hundreds of thousands of cases each year, fewer than 100 of which are reviewed by the Supreme Court (Administrative Office of the United States Courts 2013). Of course, these lower courts are embedded in the judicial hierarchy, and are supposed to adjudicate disputes as directed by the relevant precedents, particularly those issued by the Supreme Court. To ensure that they do so, and in order to resolve potential conflicts among lower courts, lower court decisions are subject to review and potential reversal by the Supreme Court.

not affect the Court's median (Carrubba et al. 2012). 
Given the prominent role of precedent in this institutional arrangement, a key challenge for lower court judges is to survey the existing stock of precedent to assess how the case before them fits into this stock - that is, to determine how the case should be decided in light of the applicable precedents. Significantly, this is a complex, challenging task. Typically, there are many potentially relevant precedents. And often, there are tensions, if not conflicts, between them. In writing an opinion, a lower court judge must therefore decide how to navigate this thicket - which opinions to acknowledge as directly relevant, which to present as inapplicable, and which to ignore. Naturally, a number of factors are likely to be influential in this process, including the jurisprudential and ideological inclinations of the judges.

As a matter of legal doctrine, one factor that lower court judges are not supposed to consider are their perceptions of the current Supreme Court's views of a precedent. This implies that changes in membership should have no bearing on the precedential value of a majority opinion. Indeed, a central element of precedent for continuing bodies like the Supreme Court is that a past decision remains authoritative even if the specific Justices who created the precedent leave the Court. The Supreme Court has stated forcefully that lower courts should not reject applicable Supreme Court decisions based on their assessment of a potential change in the Supreme Court's direction. For example, Justice Kennedy's majority opinion in Hohn v. United States (524 U.S. 236) minces no words: "Our decisions remain binding precedent until we see fit to reconsider them" $(253){ }^{2}$

Notwithstanding such pronouncements, however, lower court judges who prefer to avoid review and reversal of their decisions (Epstein and Knight 2013, Posner 1993) must consider how the current Supreme Court (which, after all, is the body that may review the judge's

\footnotetext{
${ }_{2}^{2}$ See also Rodriguez de Quijas v. Shearson/American Express, Inc., 490 U.S. 477, 484 (1989) (The Supreme Court noted that one of its opinions was inconsistent with an earlier opinion, but stated flatly: "We do not suggest that the Court of Appeals on its own authority should have taken the step of renouncing [the earlier case]. If a precedent of this Court has direct application in a case, yet appears to rest on reasons rejected in some other line of decisions, the Court of Appeals should follow the case which directly controls, leaving to this Court the prerogative of overruling its own decisions."); State Oil v. Kahn, 522 US 3, 20 (1997) ("Despite what Chief Judge Posner aptly described as Albrecht $v$. Herald Co.'s 'infirmities, [and] its increasingly wobbly, moth-eaten foundations,' there remains the question whether Albrecht deserves continuing respect under the doctrine of stare decisis. The Court of Appeals was correct in applying that principle despite disagreement with Albrecht, for it is this Court's prerogative alone to overrule one of its precedents.") (Internal citation omitted); Agostini v. Felton, 521 U.S. 203, 237 (1997) (requiring the courts of appeals to adhere to the Supreme Court's directly controlling precedents, even those that rest on reasons rejected in other decisions); Hutto v. Davis, 454 U.S. 370, 375 (1982) ("[U]nless we wish anarchy to prevail within the federal judicial system, a precedent of this Court must be followed by the lower federal courts no matter how misguided the judges of those courts may think it to be.").
} 
opinion) views the potentially applicable precedents. That is, lower court judges seeking to make their decisions less vulnerable on appeal face strong incentives to pay attention to the preferences of the contemporary Supreme Court as they decide which precedents to rely on to justify their decisions (Cameron, Segal, and Songer 2000, Kastellec 2007, Miceli and Cosgel 1994). If judges perceive that support on the Supreme Court for a particular decision may have weakened, two potential effects follow. First, circuit judges who disagree with an opinion may feel less constrained in expressing their disagreement or, less aggressively, in finding ways to avoid following the precedent without explicitly criticizing it. Second, even appeals court judges who have no qualms about a precedent may anticipate how the contemporary Court views the precedent. If they believe that the current Court is likely to be critical of a given precedent, appeals court judges may conclude that the safer course (in terms of avoiding their own reversal) is not to explicitly follow that precedent. Put differently, the anticipation that the Supreme Court may look upon the precedent with less sympathy may encourage circuit judges to engage in an explicit critique or, more modestly, to refrain from following the precedent fully (Dorf 1995, Gruhl 1981, Klein 2002). ${ }^{3}$

A number of factors are likely to lead appeals court judges to suspect that support for a decision on the contemporary Supreme Court has weakened, and to adjust their own treatment of an opinion in response. Most obviously, circuit judges may react to explicit negative treatments of an opinion by the Supreme Court itself (Hansford and Spriggs 2006). Similarly, ideological change between the Supreme Court majority that issued a precedent and the current Supreme Court suggests that the current Court may take a more critical view of a precedent. It is precisely for this reason that scholars have argued that ideological shifts between the enacting and contemporary Supreme Court will lead lower courts to treat opinions less favorably, and a number of studies provide strong evidence for such an effect (e.g., Gruhl 1981, Hansford and Spriggs 2006, Klein 2002, Westerland et al. 2010). Given that the retirement of Supreme Court Justices and their replacement with new Justices affects the ideological composition of the Court, retirements are therefore (indirectly) relevant for how lower courts treat precedents.

\footnotetext{
${ }^{3}$ In addition to this positive literature, there is also a longstanding normative debate among legal academics about whether appeals courts should predict how the contemporary Supreme Court will respond to one of its precedents. Some reject the Supreme Court's position that lower courts should not do so, and others offer support for the Supreme Court's position (Dorf 1995, Caminker 1994, Posner 1990, Bhagwat 2000, Bradford 1990).
} 
The central argument of this paper is that such retirement-induced ideological change is not the only manner in which retirements matter for how lower courts treat precedent. We argue that in addition to this indirect effect, retirements also have a direct negative effect on how lower courts treat opinions: Lower court judges do not merely focus on ideological change (What is the balance of conservative and liberal Justices?). They also take note of the fact that the particular Justices who joined a decision retire. There are two (related) reasons why we expect judicial retirements have this effect. First, judicial retirements are correlated with, but separate from, general ideological shifts on the Court. For one, ideological shifts can occur even in the absence of change in Court membership as the views of Justices evolve (this is, obviously, a major impetus behind dynamic measures of Supreme Court ideology, such as the Martin-Quinn (2002) scores). More importantly, ideological shifts that are measured along a traditional liberalconservative dimension do not capture differences in views that are orthogonal to ideology, and can exist even among Justices of a similar ideological persuasion. How Justices view cases is a complex phenomenon, affected by ideology, interpretive commitments, life experiences, and other (perhaps idiosyncratic) factors (Posner 2008). The manner in which Justices view opinions is bound up - at least to some extent - in factors that are tied to their specific experiences and temperament. One particularly important factor in this context is that Justices may feel more personally attached to opinions they joined than to opinions they did not join. As a result, a new set of Justices may take a different view of cases previously decided, even if they share the general ideological predispositions of their predecessors.

This reasoning is reinforced by the fact that in addition to plausibly affecting current support for a precedent, turnover on the Supreme Court is easy to spot - an important factor given the complexity of the task confronting lower court judges. The retirement of Justices who were part of an opinion's majority acts as a simple heuristic for lower court judges looking for evidence that support on the Supreme Court for a particular precedent may have weakened. Moreover, this signal becomes stronger as fewer and fewer of the Justices who joined an opinion remain on the Court. Consider a lower court judge confronting a precedent for which all the Justices from the original majority coalition remain on the Court. In this setting, it is natural for a lower court judge to believe that faithful adherence to the precedent may help to insulate her decision against review, and that failure to do so risks antagonizing a majority of the Supreme Court. In contrast, as more and more of the Justices in the original majority leave the Court and are replaced by new Justices, the situation changes. An increasing number of the Justices on the 
current Supreme Court have not explicitly signed on to the precedent, and the new Justices may see the precedent differently. ${ }^{4}$ All else equal, the lower court judge may feel under less pressure to explicitly follow the opinion, and may even feel safe in casting doubt on or limiting it. This argument leads to the following expectation:

\section{Hypothesis ("Retirement Effect on Lower Court Treatments"): Ceteris} paribus, lower court judges are less likely to follow a Supreme Court precedent as more of the Justices who signed on to the opinion retire from the Court. Similarly, lower court judges are more likely to treat an opinion negatively as more of the Justices who signed on to the opinion retire from the Court.

\section{DATA AND MEASURES}

To test this hypothesis, we require data on how lower courts interact with relevant Supreme Court precedents. Since judges on the courts of appeals occupy the level below the Supreme Court, and are directly open to review and reversal by the Supreme Court, we focus our analysis on them. ${ }^{5}$ To measure the subsequent treatment of Supreme Court majority opinions in the courts of appeals, we rely on Shepard's Citations, an approach that has become standard in the literature (e.g., see Benjamin and Desmarais 2012, Corley 2009, Hansford and Spriggs 2006, Westerland et al. 2010). Shepard's is a widely used, commercial legal research company that employs attorneys who examine every published state and federal court opinion, and engage in a content analysis of every citation in those opinions. Citations that have a substantive treatment of an opinion (i.e., discuss it rather than just mentioning it) are classified into the following main categories: Overruled, Criticized, Questioned, Limited, Distinguished, Explained, Harmonized, or Followed. Shepard's characterizes Overruled, Criticized, Questioned, Limited, and Distinguished as negative treatments. Of these, the first four are viewed as "strongly negative,"

\footnotetext{
${ }^{4}$ Put simply, the clearest indication of a Justice's support for a given majority opinion is her joining of it. A Justice who arrives after the opinion is decided cannot give that indication. Note in this regard that in only four cases in its history has the Supreme Court overruled one of its cases without a change in membership (Gerhardt 2005: 952).

${ }^{5}$ Of course, there are also district courts below the courts of appeals. But district court judges' opinions are appealed to circuit courts (each of which has its own circuit jurisprudence to which stare decisis applies within the circuit). As a result, for district judges, the immediate reviewer is the circuit court, and review by the Supreme Court is a more distant concern. We therefore focus on circuit judges, for whom the only reviewer is the Supreme Court.
} 
while Distinguished is classified as a mildly negative treatment. Followed - the most common treatment - is characterized as a positive treatment. ${ }^{6}$ Finally, Explained and Harmonized are neutral. Spriggs and Hansford (2000) investigate the reliability of Shepard's by independently coding a stratified sample of Supreme Court cases, and find high levels of agreement between their coding and Shepard's.

Because our argument leads to the expectation that circuit court judges will become less likely to follow a precedent, and more likely to cast doubt on it, as more Justices who joined a majority opinion retire from the Supreme Court, we focus on strongly negative treatments and on Followed. The key dependent variable for our analysis is the count of the number of strongly negative and Followed treatments of a given Supreme Court opinion in a particular year. To construct our data, we begin with all orally argued cases in which the Supreme Court issued a signed majority opinion in the 1953-2012 terms, as reported by the U.S. Supreme Court Database (Spaeth et al. 2013). ${ }^{7}$ We then use Shepard's to generate an annual count of the number of strongly negative treatments and Followed treatments for each of these Supreme Court opinions in courts of appeals opinions issued between 1953 and the end of $2012 .{ }^{8}$ In other words, the unit of observation in the dataset is the "opinion-year," organized by Supreme Court opinion (beginning with the year in which the opinion was issued), a structure that makes sense given our interest in how opinions are treated over time. Finally, we combine these data with information on the retirement dates of the Justices who constituted the majority in each case, allowing us to construct the measures discussed in more detail below. The full dataset comprises 5,813 majority opinions and 188,424 opinion-years.

As we noted above, a strongly negative treatment of a Supreme Court opinion is a risky move for a circuit judge. Instead of simply citing or ignoring an earlier case, the lower court criticizes, questions, or limits a Supreme Court opinion and thereby casts doubt on it. In so doing, the circuit court draws attention to itself and risks rebuke. Not surprisingly, such treatments are generally rare. As the aggregate data displayed in Table 1 make clear, roughly

\footnotetext{
${ }^{6}$ In addition to Followed, Shepard's also identifies a treatment called Paralleled that is characterized as positive. However, this treatment is exceedingly rare - so rare, in fact, that in the courts of appeals data we employ below there is not a single instance of a court of appeals treatment that is classified as Paralleled.

${ }^{7}$ These are those opinions coded as "decisionType $=1$ " in the Supreme Court Database.

${ }^{8}$ Only the Supreme Court can overrule its own cases, so lower courts' negative reactions cannot include an overruling. Our data encompass the available strongly negative treatments of a Supreme Court opinion by a lower court - Criticized, Questioned, and Limited.
} 
$83 \%$ of opinions are never criticized, questioned, or limited in this explicit fashion, and only $2 \%$ of opinions receive 4 or more strongly negative treatments. By contrast, following a precedent that is on point is the expected and obvious way for circuit courts to engage with Supreme Court opinions. As this reasoning suggests, Followed is a far more common substantive treatment. Note, however, that even for Followed, more than $50 \%$ of opinions receive seven or fewer such treatments. In order to evaluate changes in treatments over time, we must further break down the data into yearly treatments of Supreme Court opinions. As Table 2 shows, once we do so, opinions are not strongly criticized in the vast number of years. Followed treatments are more common, but even there, most opinions are not positively treated on an annual basis. ${ }^{9}$

\section{Table 1 about here}

Table 2 about here

\section{A. Explanatory Variables}

Our argument implies that circuit court judges use the retirement of Supreme Court Justices as a simple heuristic suggesting that support for a decision may have weakened. As a result, as more Justices from the original majority coalition retire, the willingness of circuit judges to faithfully follow the precedent decreases, and their willingness to openly criticize it increases. Importantly, we expect this effect while controlling for more general ideological change on the Supreme Court, both because general ideological change is unlikely to capture idiosyncratic differences among Justices and because the retirement of Justices who signed on to an opinion is easier for circuit judges to spot than ideological change. To capture this retirement effect, we employ a variable that indicates the number of Justices from the original majority coalition that remain on the current Supreme Court during a particular year. For example, for a 7-2 decision, this variable takes the value 7 as long as all Justices from the majority coalition remain on the Court, drops to 6 as the first Justice retires, and so on. The expectation expressed in our hypothesis is that as the number of Justices who signed on to an opinion and who remain on the Supreme Court declines, opinions will be treated in a strongly negative fashion more often, and will be followed less often.

\footnotetext{
9 The fact that a considerable number of opinion-years feature no strongly negative or Followed treatments raises potential methodological challenges that we address below.
} 
As outlined above, we believe that this retirement effect is separate from the impact of general ideological change on the Supreme Court, which is (of course) itself partly a function of judicial retirements. Put differently, we want to clearly distinguish the impact of judicial retirements from the impact of general ideological change. To do so, we control for the absolute shift in the location of the median Justice on the Supreme Court that issued the cited opinion and the current Supreme Court, as measured by the Martin-Quinn (2002) scores, the most widelyused, dynamic estimate of the Justices' preferences. We expect that as this distance increases, circuit courts will more often treat a Supreme Court opinion in a strongly negative manner. Conversely, we expect that the number of Followed treatments will decrease. Indeed, previous work has found evidence consistent with this expectation. Benjamin and Desmarais (2012) show that the aggregate number of negative treatments increases with the average distance between Supreme Court medians, and Spriggs and Hansford (2001) have demonstrated that the Supreme Court is more likely to overrule a precedent the greater the ideological distance between the decision-median and the contemporary median (see also Hansford and Spriggs 2006). Similarly, Westerland et al. (2010) show that increasing distance between the median member of the opinion coalition and the contemporary Supreme Court median significantly reduces compliance with precedents by circuit court panels.

\section{B. Additional Control Variables}

Of course, there are a number of other factors that are likely to affect the treatment of Supreme Court opinions by appeals courts, and we need to control for these in our analysis. We can usefully group these into characteristics of the cited Supreme Court opinion that may directly affect how a decision is received, and dynamic factors that capture changes in the legal environment (relative to the environment in which the original decision was issued) that may affect how a decision is treated.

As previous work has shown, the most important characteristics of Supreme Court opinions that affect their subsequent treatment are the number of Justices who signed on to the opinion, the ideological range of the majority coalition, and the number of concurrences published alongside the opinion (Benjamin and Desmarais 2012, Westerland et al. 2010). The intuition for why these characteristics matter is immediate: One would expect that appeals courts are less likely to treat negatively and more likely to treat positively opinions that announce legal rules that are broadly acceptable and sensible to judges and lawyers across the ideological and 
jurisprudential spectrum. The three characteristics indicate opinions for which this is likely to be the case: The greater the number of Justices who sign on to an opinion, and the broader the ideological range of that coalition (which we measure by the range of the majority in terms of Martin-Quinn scores), the more broadly acceptable the decision is likely to be. We thus expect these variables to reduce the number of strongly negative treatments, and to increase the number of Followed treatments during a given year. In contrast, a greater number of concurring opinions signals that there are alternative legal justifications for the outcome reached in a case, which signals that the opinion is less broadly acceptable. We thus expect the number of concurrences to increase the number of strongly negative treatments and to decrease the number of Followed treatments. Prior work provides evidence consistent with these expectations. For example, Benjamin and Desmarais (2012) show that aggregate strongly negative treatments of opinions increase with the number of published concurrences, and decrease for larger majority coalitions, and for broader coalitions. Similarly, Spriggs and Hansford (2001) find that the probability that an opinion will be overruled rises in the number of concurrences. ${ }^{10}$

In addition to controlling for the ideological shift of the Supreme Court, we control for several factors that may affect the number of strongly negative or Followed treatments. One factor concerns the preferences of the courts of appeals relative to the Supreme Court that issued an opinion: One would expect that insofar as lower court judges are ideologically more distant from the Supreme Court that issued an opinion, they would be more inclined to negatively treat, and less inclined to follow, a precedent. Controlling for circuit court preferences poses a challenge: Our data represent a count of treatments of Supreme Court opinions across the courts of appeals in a given year. Therefore, we focus on the aggregate preferences of the courts of appeals relative to the Supreme Court. Specifically, for each Supreme Court opinion-year, we include the absolute difference between the number of Democratic appointees on the Supreme Court that issued an opinion and the number of Democratic appointees of the courts of appeals in that year, a standard approach (see McGuire et al. 2009). We expect that as this difference increases, the number of strongly negative treatments will increase, and the number of Followed treatments will decline.

\footnotetext{
${ }^{10}$ In contrast, in their random sample of 500 Supreme Court opinions, Westerland et al. (2010) find that the number of concurrences has a small positive impact on the probability of compliance. However, they do not discuss this finding.
} 
Strongly negative treatments are more likely, and Followed treatments less likely, after the Supreme Court itself has treated an opinion negatively, thus sending a signal to appeals courts that an opinion is open to criticism (Westerland et al. 2010). This effect should get stronger the more often the Supreme Court has treated an opinion negatively. We thus include a count of the number of times an opinion has been treated negatively by the Supreme Court. Similarly, if an opinion is explicitly overruled by the Supreme Court, we would of course expect appeals courts to treat this opinion more negatively and less positively (Benesh and Reddick 2002). We control for this possibility by including a binary variable that indicates opinion-years after an opinion has been overruled. Because opinions may become less relevant over time, we include the age of the opinion. Finally, we must take account of the fact that opinions do not have equal opportunities to be treated negatively or positively. Opinions vary in the extent to which they are pertinent to the issues currently before the courts of appeals. Some decisions are relevant in many cases, and thus are cited frequently. Others are more obscure and cited infrequently. Naturally, an opinion that is relevant in many cases, and is cited often, has a higher likelihood of being treated negatively or positively than an opinion that is hardly ever relevant, and therefore has few opportunities to be treated negatively or positively. To capture this, we include the (logged) count of the number of times an opinion is Followed in a given year in the federal district courts. $^{11}$

\section{ESTIMATION AND RESULTS}

Because our dependent variable is a count of the number of times a given Supreme Court opinion is treated in a strongly negative or positive fashion by the courts of appeals in a given year, we employ count models to test our hypothesis. Typically, the primary quantity of interest in a count model is the incidence rate over an observation period. This incidence rate has a systematic component, usually modeled as an exponential function of a set of covariates, as well as a stochastic component. The stochastic component is often assumed to follow a Poisson distribution, which implies that events (in our case, treatments of Supreme Court opinions) are conditionally independent. This is a strong assumption that is likely violated in our data: Once an opinion has been criticized by a lower court, for example, it may be easier for the same court (or

\footnotetext{
${ }^{11}$ To be precise, we use $\ln (\#$ of contemporary Follows+1) in order to deal with the fact that some opinions are not treated at all during some years.
} 
another court of appeals) to do so again. The result of such positive contagion is overdispersion in the data, which results in a downward bias in standard errors (King 1989). To deal with this problem, researchers typically assume that the stochastic component of the incidence rate follows a negative binomial distribution, a solution we adopt as well. ${ }^{12}$

In so doing, we must confront two additional challenges. One relates directly to the issue of overdispersion. Our data has a panel structure: We observe the treatment of separate Supreme Court opinions over time, and it is likely that overdispersion does not affect each opinion in the same way. This is a common challenge in panel datasets. The standard way to address such unit heterogeneity is to estimate a random-effects negative binomial model that allows the dispersion parameter to vary randomly across units (Hilbe 2011). In our specific case, this means that the dispersion parameter is assumed to be constant for each opinion, but can vary randomly across opinions. $^{13}$

The second challenge concerns the large number of observations (opinion-years) for which no treatment is recorded, especially in our analysis of strongly negative treatments. The presence of a large number of zeros in the dependent variable suggests that separate processes may drive whether an opinion is ever treated, and how often it is treated once it attracts the attention of the lower courts. Statistically, in such situations, the use of zero-inflated negative binomial models may be appropriate (King 1989: 222f., Zorn 1998). Such models estimate two separate equations - one to predict the presence of no incidents, and one to model the count, where the count is positive. However, these models involve a difficult tradeoff: zero-inflated negative binomial models are not able to take account of the heterogeneity in the dispersion parameter that is addressed through a random effects negative binomial model. We confront this challenge by estimating both types of models. The results are broadly comparable. Because the random-effects model accounts for panel effects across opinions, we opt to present this model in the main text. Results from the zero-inflated model are provided in the appendix.

\footnotetext{
${ }^{12}$ One indication of overdispersion in the dependent variable is a standard deviation that is larger than the mean of the dependent variable; in our data, this is the case for both strongly negative treatments and Followed treatments. Supplemental results from a Poisson model, which yields similar results, are included in the replication file available at http:[REMOVED].

${ }^{13}$ All models are estimated using STATA 13, which implements this kind of model through the xtnbreg command.
} 


\section{A. Results: Negative Treatments}

We begin our analysis by investigating how often an opinion will be explicitly criticized, questioned, or limited in a courts of appeals decision during a given year, i.e., the number of times an opinion receives a treatment classified as strongly negative by Shepard's. In Table 3, we report results from a random effects negative binomial model (with bootstrapped standard errors), predicting the count of strongly negative treatments of a given Supreme Court opinion during a given year in courts of appeals decisions. Before focusing on the effects of the key explanatory variables, note that the control variables are largely in line with the existing literature. Once a case has been overruled, it attracts a larger number of strongly negative treatments in the courts of appeals. Strongly negative treatments occur more rarely for opinions signed by larger majorities, while opinions accompanied by concurrences attract a larger number of strongly negative treatments. Opinions that are relevant for a greater number of cases, as indicated by the fact that they are followed more often in the district courts, attract more strongly negative treatments - a result that we interpret as evidence of the fact that opinions that come up in many cases are at greater risk of being criticized simply because there are more opportunities to do so. As opinions age, they attract fewer strongly negative treatments. Interestingly, we find no statistically significant effect of the range of the coalition that supported the opinion, the ideological shift between the enacting and current Supreme Court, or the enacting Supreme Court and the overall ideological leaning of the courts of appeals.

\section{Table 3 about here}

Turning to our main variable of interest - the number of Justices in the original majority coalition who remain on the Court - we find strong evidence consistent with our hypothesis. The estimated coefficient is negative and statistically significant, indicating that opinions receive more strongly negative treatments as more Justices from the original majority retire. Importantly, this effect is evident while controlling for general ideological change and the age of the opinion. This provides strong support for our hypothesis.

Because estimated coefficients of count models are difficult to interpret directly, we illustrate the substantive impact and the uncertainty surrounding our estimates graphically. Figure 1 plots the predicted number of strongly negative treatments per year conditional on the number of Justices who remain on the Court from the original majority coalition, along with $95 \%$ 
confidence intervals. The top panel shows this predicted number for unanimous opinions, the second panel for 7-2 decisions, and the final panel for 5-4 decisions. The results are strikingly consistent with the hypothesis. The predicted number of strongly negative treatments of a Supreme Court opinion in the courts of appeals rises as the Justices who constituted the original majority coalition retire. Moreover, the substantive size of the effect is significant: For unanimous opinions, there is a roughly nine-fold increase in the expected number of strongly negative treatments as the Justices who joined the decision retire until none are left on the Court. For 7-2 decisions, the increase is roughly four-fold, while it is close to three-fold for 5-4 decisions. The absolute number of predicted strongly negative treatments is small. But, as we noted above, strongly negative treatments represent a highly risky strategy for circuit court judges, and that these are predicted counts of strongly negative treatments for a specific decision in a specific year.

\section{Figure 1 about here}

\section{B. Results: Positive Treatments (Followed)}

Explicit negative treatments represent an extreme form of trying to limit the impact of a relevant precedent and may, in this sense, be much like the tip of the proverbial iceberg. Rather than engaging in overt resistance, circuit court judges who wish to avoid the implications of a relevant precedent are more likely to engage in a less confrontational style of noncompliance: They can simply refrain from following a precedent. And just as they may feel more comfortable openly criticizing an opinion as the Justices who supported it retire from the Supreme Court, so circuit court judges may feel less pressure to explicitly follow an opinion as the Justices who supported the decision retire. We now turn to an analysis of this phenomenon.

In Table 4, we present the results of a random-effects, negative binomial model of the number of explicit Followed treatments of a Supreme Court opinion in a given year with bootstrapped standard errors. As in the previous analysis, the random effects estimation assumes that the dispersion parameter is constant for any opinion, but can vary randomly across opinions. Before turning to the key variable of interest, note that the control variables largely continue to have the expected impact - in fact, the results are even stronger than for the negative treatments. Most importantly, increasing ideological distance between the enacting Supreme Court and the contemporary Supreme Court results in a smaller number of Followed treatments - that is, circuit 
judges are less likely to explicitly follow a precedent if the Court that enacted the precedent is ideologically distant from the current Supreme Court. Similarly, as the courts of appeals as a whole are ideologically more distant from the enacting Supreme Court, fewer Followed treatments are predicted. Similarly, opinions that have been explicitly overruled by the Supreme Court generate a smaller number of Follows. Interestingly, opinions supported by broader coalitions - both in terms of the number of majority votes, as well as the ideological range of the opinion coalition - result in fewer Followed treatments, a finding that stands in contrast to the results for strongly negative treatments.

Of course, the main variable of interest is the number of Justices remaining of the original majority coalition. Once again, the results clearly support our expectations. As the Justices who originally joined a decision leave the Court, the number of Followed treatments begins to drop, and this impact is statistically highly significant. As before, we turn to a graphic illustration to demonstrate the substantive impact of this effect. In Figure 2, we plot the predicted number of Followed treatments for an opinion in a given year, conditional on the number of Justices remaining of the original majority (along with 95\% confidence intervals). Once again, the top panel illustrates the impact for unanimous decisions, the middle panel for 7-2 decisions, and the bottom panel for 5-4 decisions.

\section{Table 4 about here}

\section{Figure 2 about here}

The message of Figure 2 is striking: As the Justices in the original majority coalition retire, there is a statistically highly significant and substantively massive decrease in the propensity of circuit courts to explicitly follow the opinion - the predicted number of Followed treatments per year falls by roughly $70 \%$ (unanimous decisions) to 100\% (5-4 decisions). Put simply, as those Justices who explicitly supported a Supreme Court decision retire, circuit court judges are significantly less likely to feel the need to explicitly follow the precedent in cases before them.

\section{CONCLUSION}

The U.S. Supreme Court has a tremendous impact on social, economic, and political outcomes in the US despite the fact that the Court itself revolves only a small number of disputes 
each term. Instead, much of the Court's influence is indirect. The opinions issued by the Court steer the decisions of lower courts - and it is in these lower courts that the vast bulk of legal disputes are resolved. The prominent role of lower courts in giving life to the jurisprudential doctrines announced by the Supreme Court raises a critical question: Given that lower court judges must typically choose among a host of potentially relevant precedents, some of which may conflict with one another, what makes a particular Supreme Court opinion more or less influential in the lower courts? Scholars have long recognized the importance of this question, and a well-established literature has explored factors that lead lower court judges to treat opinions more or less favorably. We now know that the size and breadth of majority coalitions, the number of concurrences, and the extent of ideological change on the Supreme Court all contribute to how opinions are received in the lower courts (Benesh and Reddick 2002; Benjamin and Desmarais 2012; Black and Spriggs 2008; Corley 2009, Westerland et al. 2010, Hansford and Spriggs 2006).

In this paper, we have examined a factor that has so far escaped sustained examination: The impact of the departure of Justices who supported a Supreme Court opinion. We have argued that despite the Supreme Court's insistence that lower courts should not engage in prognostication in anticipating the views of the Supreme Court on relevant precedents, judges in the lower courts face strong incentives to interpret the past decisions in ways that the current Supreme Court will accept. Doing so minimizes the risk of suffering the embarrassment of being reversed or reprimanded, and allows the lower court's decision to go into effect. The retirement of Supreme Court Justices is critical in this context, because the departure of Justices who signed on to an opinion, and their replacement by new Justices can signal to lower court judges that support for the opinion on the current Supreme Court may have weakened. Moreover, such retirements are a particularly simple and easily observed heuristic. As a result, we expect that the influence of Supreme Court opinions is subject to a retirement effect: Controlling for the degree of ideological change on the Supreme Court, lower court judges are more likely to criticize Supreme Court opinions and less likely to follow them as the Justices who joined the decision retire. The smaller the number of Justices who remain from the original majority coalition, the stronger this effect will become. Our empirical results, which are based on tracking the annual treatment of all Supreme Court majority opinions in the courts of appeals between 1953 and 2012, provide clear and substantively significant support for this argument: As the Justices who signed on to an opinion retire from the Court, the propensity of lower court judges to follow the 
opinion drops significantly, and the willingness of lower court judges to explicitly criticize the opinion increases.

These findings have important implications for our understanding of Supreme Court precedents and the effects of personnel turnover on the Supreme Court. The Court sees itself as a continuing body, and of course it is. But for purposes of its precedents, each new Court (that is, after each departure and replacement) is a new entity, and lower court judges are likely to react to the fact that Justices who joined a decision are no longer present. This implies that the significance of the replacement of one Justice by another extends beyond the impact on future decisions by the Supreme Court itself. Such a change also affects how existing case law is applied in the judicial hierarchy. If a Justice wants a precedent to retain force in the lower courts, she should remain on the Court, and encourage other members of the majority to remain as well. 
Table 1: Number of Strongly Negative and Positive Treatments of Supreme Court Majority Opinions in the Courts of Appeals, 19532012

\begin{tabular}{lcc}
$\begin{array}{c}\text { \# of } \\
\text { Treatments }\end{array}$ & $\begin{array}{c}\text { Strongly } \\
\text { Negative } \\
\text { Treatments }\end{array}$ & $\begin{array}{c}\text { Positive } \\
\text { Treatments }\end{array}$ \\
\hline \hline None & $\begin{array}{c}4,795 \\
(83 \%)\end{array}$ & $\begin{array}{c}682 \\
(12 \%)\end{array}$ \\
& 894 & 1,367 \\
$1-3$ & $(15 \%)$ & $(23 \%)$ \\
$4-7$ & 71 & 1,063 \\
& $(1 \%)$ & $(17 \%)$ \\
8 or more & 53 & 2,701 \\
& $(1 \%)$ & $(48 \%)$ \\
\hline \hline $\begin{array}{c}\text { Number of } \\
\text { Opinions }\end{array}$ & 5,813 & 5,813
\end{tabular}

Table 2: Number of Strongly Negative and Positive Treatments of Supreme Court Majority Opinions in the Courts of Appeals on an Annual Basis, 1953-2012

\begin{tabular}{lcc}
$\begin{array}{c}\text { \# of } \\
\text { Treatments } \\
\text { per year }\end{array}$ & $\begin{array}{c}\text { Strongly } \\
\text { Negative } \\
\text { Treatments }\end{array}$ & $\begin{array}{c}\text { Positive } \\
\text { Treatments }\end{array}$ \\
\hline \hline \multirow{2}{*}{ None } & $\begin{array}{c}186,467 \\
(99 \%)\end{array}$ & $\begin{array}{c}145,240 \\
(77 \%)\end{array}$ \\
& 1,634 & 23,321 \\
1 & $(0.9 \%)$ & $(12.5 \%)$ \\
& 244 & 12,233 \\
$2-3$ & $(0.1 \%)$ & $(6.5 \%)$ \\
& 79 & 7,630 \\
4 or more & $(0 \%)$ & $(4 \%)$
\end{tabular}

Number of

Opinion-

188,424

188,424

Years 
Table 3: Strongly Negative Treatments of Supreme Court Majority Opinions in the Courts of Appeals, 1953-2012

\begin{tabular}{|c|c|c|}
\hline \# of majority Justices remaining & $\begin{array}{r}-0.208 \\
(0.028)\end{array}$ & **** \\
\hline Shift in SC medians & $\begin{array}{r}0.014 \\
(0.079)\end{array}$ & \\
\hline Shift between SC and CoA & $\begin{array}{r}-0.007 \\
(0.005)\end{array}$ & \\
\hline \# of majority votes & $\begin{array}{r}-0.071 \\
(0.029)\end{array}$ & $* *$ \\
\hline Range of majority & $\begin{array}{r}-0.003 \\
(0.020)\end{array}$ & \\
\hline \# of concurrences & $\begin{array}{r}0.114 \\
(0.045)\end{array}$ & $* *$ \\
\hline Strongly negative treatments by SC & $\begin{array}{r}-0.083 \\
(0.089)\end{array}$ & \\
\hline Case overruled & $\begin{array}{r}3.092 \\
(0.036)\end{array}$ & $* * *$ \\
\hline $\begin{array}{l}\text { \# of contemporary follows in District } \\
\text { Courts (log) }\end{array}$ & $\begin{array}{r}0.307 \\
(0.036)\end{array}$ & $* * *$ \\
\hline Opinion age & $\begin{array}{r}-0.065 \\
(0.006)\end{array}$ & $* * *$ \\
\hline Constant & $\begin{array}{r}0.207 \\
(0.230)\end{array}$ & \\
\hline $\ln (r)$ & $\begin{array}{r}1.949 \\
(0.099)\end{array}$ & \\
\hline $\ln (s)$ & $\begin{array}{r}-1.082 \\
(0.079)\end{array}$ & \\
\hline $\mathrm{N}$ of opinion-years & 188,424 & \\
\hline $\begin{array}{l}\mathrm{N} \text { of opinions } \\
\mathrm{BIC} \\
\mathrm{AIC}\end{array}$ & $\begin{array}{r}5,813 \\
20,620 \\
20,488\end{array}$ & \\
\hline
\end{tabular}

NOTE: Dependent variable is \# of strongly negative treatments in a Court of Appeals decision in a given year. Random effects, negative binomial regression with bootstrapped standard errors. *** significant at $0<0.01, * *$ significant at $\mathrm{p}<0.05, *$ significant at $\mathrm{p}<0.10$. 
Table 4: Positive Treatments of Supreme Court Majority Opinions in the Courts of Appeals, 1953-2012

\begin{tabular}{|c|c|c|}
\hline \# of majority Justices remaining & $\begin{array}{r}0.070 \\
(0.008)\end{array}$ & **** \\
\hline Shift in SC medians & $\begin{array}{r}-0.185 \\
(0.020)\end{array}$ & $* * *$ \\
\hline Shift between SC and CoA & $\begin{array}{r}-0.005 \\
(0.001)\end{array}$ & $* * *$ \\
\hline \# of majority votes & $\begin{array}{r}-0.032 \\
(0.018)\end{array}$ & $*$ \\
\hline Range of majority & $\begin{array}{r}-0.035 \\
(0.015)\end{array}$ & $* *$ \\
\hline \# of concurrences & $\begin{array}{r}0.141 \\
(0.026)\end{array}$ & $* * *$ \\
\hline Strongly negative treatments by SC & $\begin{array}{r}0.036 \\
(0.040)\end{array}$ & \\
\hline Case overruled & $\begin{array}{r}-0.543 \\
(0.089)\end{array}$ & $* * *$ \\
\hline $\begin{array}{l}\text { \# of contemporary follows in District } \\
\text { Courts }(\log )\end{array}$ & $\begin{array}{r}0.499 \\
(0.013)\end{array}$ & $* * *$ \\
\hline Opinion age & $\begin{array}{r}-0.013 \\
(0.002)\end{array}$ & $* * *$ \\
\hline Constant & $\begin{array}{r}0.459 \\
(0.121)\end{array}$ & \\
\hline $\ln (r)$ & $\begin{array}{r}1.239 \\
(0.044)\end{array}$ & \\
\hline $\ln (s)$ & $\begin{array}{r}-0.085 \\
(0.027)\end{array}$ & \\
\hline $\mathrm{N}$ of opinion-years & 188,424 & \\
\hline $\begin{array}{l}\mathrm{N} \text { of opinions } \\
\mathrm{BIC} \\
\mathrm{AIC}\end{array}$ & $\begin{array}{r}5,813 \\
260,472 \\
260,340\end{array}$ & \\
\hline
\end{tabular}

NOTE: Dependent variable is \# of "follow" treatments in a Court of Appeals decision in a given year. Random effects, negative binomial regression with bootstrapped standard errors. $* * *$ significant at $0<0.01, * *$ significant at $\mathrm{p}<0.05, *$ significant at $\mathrm{p}<0.10$. 
Figure 1: Predicted number of strongly negative treatments/year conditional on number of Justices remaining from the original majority
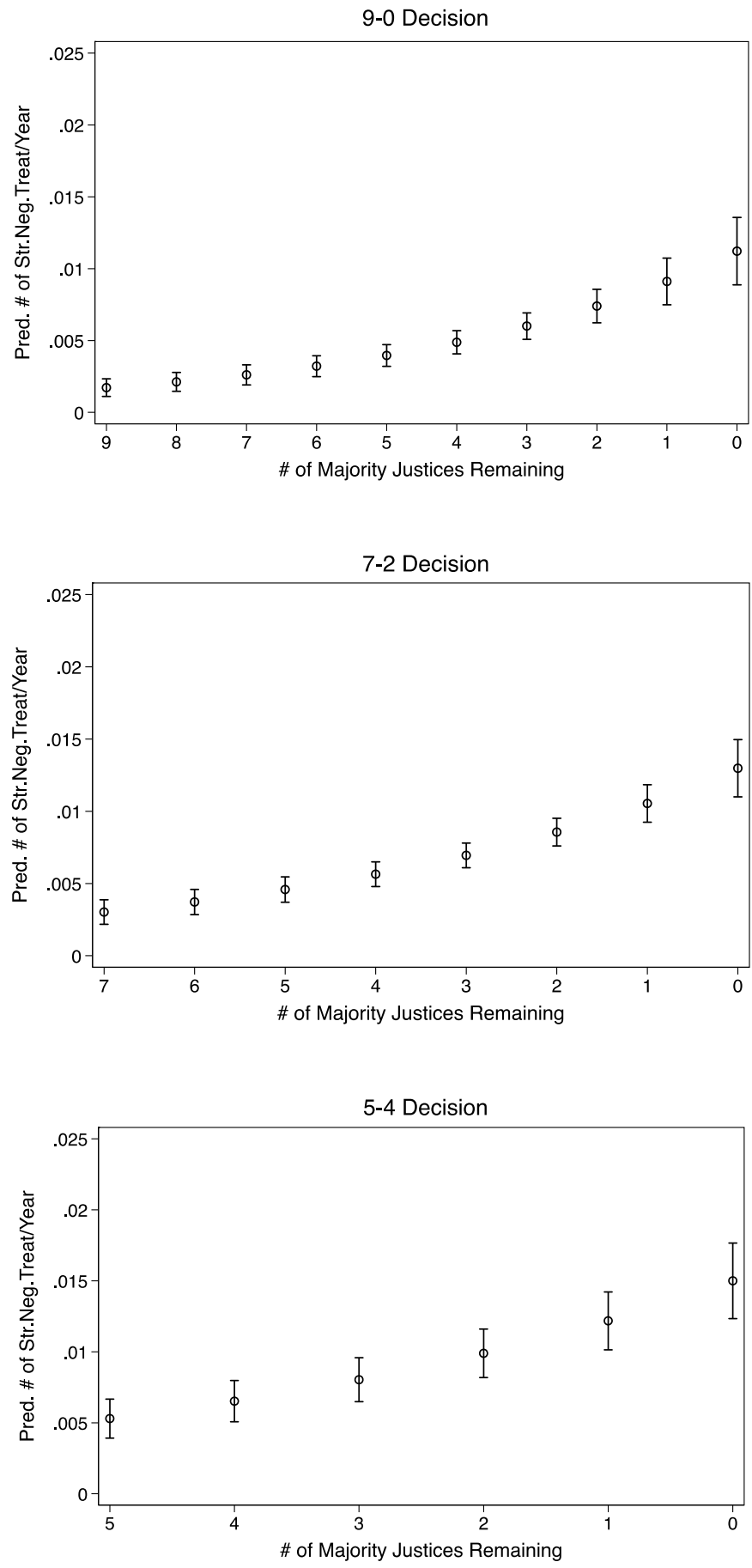
Figure 2: Predicted number of Followed treatments/year conditional on number of Justices remaining from the original majority
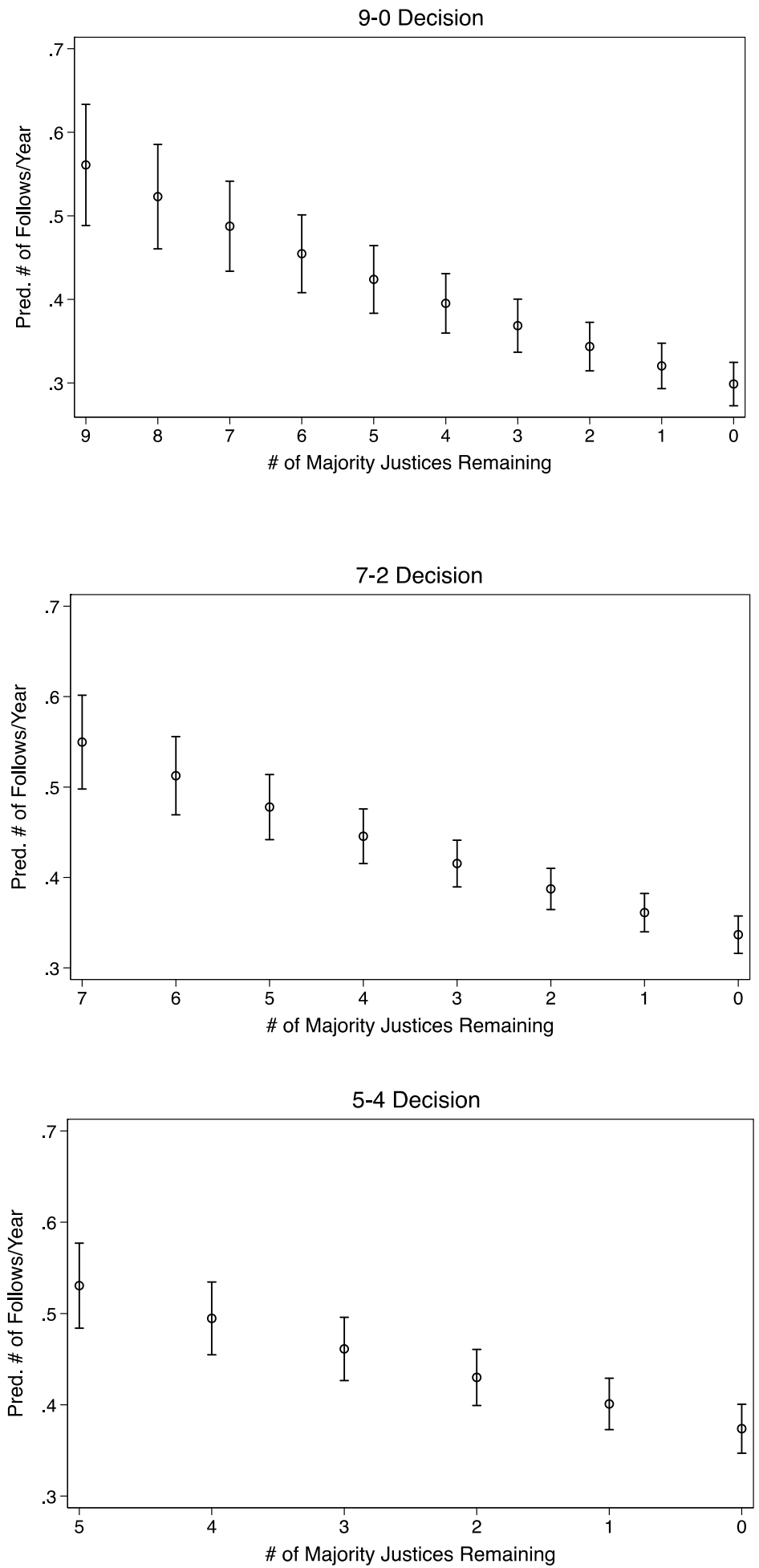


\section{References:}

Ackerman, Bruce. 1988. “Transformative Appointments.” Harvard Law Review 101: 1164-1184.

Administrative Office of the United States Courts, Annual Report of the Director (2013), available at http://www.uscourts.gov/Statistics/JudicialBusiness/2013.aspx.

Baum, Lawrence. 1978. "Lower-Court Response to Supreme Court Decisions: Reconsidering a Negative Picture." Justice System Journal 3: 208-219.

Baum, Lawrence. 1992. "Membership Change and Collective Voting Change in the United States Supreme Court." Journal of Politics 54: 3-24.

Benesh, Sara C., and Malia Reddick. 2002. "Overruled: An Event History Analysis of Lower Court Reaction to Supreme Court Alteration of Precedent." Journal of Politics 64: 534550 .

Benjamin, Stuart M., and Bruce Desmarais. 2012. "Standing the Test of Time: The Breadth of Majority Coalitions and the Fate of U.S. Supreme Court Precedents, Journal of Legal Analysis 4: 445-469.

Bhagwat, Ashutosh. 2000. "Separate But Equal?: The Supreme Court, the Lower Federal Courts, and the Nature of the 'Judicial Power'." Boston University Law Review 80: 967-1015.

Black, Ryan C. \& James F. Spriggs II. 2008. "An Empirical Analysis of the Length of U.S. Supreme Court Opinions." Houston Law Review 45: 621-682.

Bradford, C. Steven. 1990. "Following Dead Precedent: The Supreme Court's Ill-Advised Rejection of Anticipatory Overruling." Fordham Law Review 59: 39-90.

Cameron, Charles, Jeffrey Segal, and Donald Songer. 2000. "Strategic Auditing in a Political Hierarchy: An Informational Model of the Supreme Court's Certiorari Decisions." American Political Science Review 94: 101-116.

Caminker, Evan H. 1994. "Precedent and Prediction: The Forward-Looking Aspects of Inferior Court Decisionmaking." Texas Law Review 73: 1-82.

Canon, Bradley and Charles Johnson. 1999. Judicial Policies: Implementation and Impact. Washington, DC: CQ Press.

Corley, Pamela C. 2009. "Uncertain Precedent: Circuit Court Responses to Supreme Court Plurality Opinions." American Politics Research 37: 30-49.

Dorf, Michael C. 1995. "Prediction and the Rule of Law." UCLA Law Review 42: 651-715.

Epstein, Lee and Jack Knight. 2013. "Reconsidering Judicial Preferences." Annual Review of Political Science 16: 11-31. 
Gerhardt, Michael J. 2005. "The Limited Path Dependency of Precedent." University of Pennsylvania Journal of Constitutional Law 7: 903-1000.

Gruhl, J. 1981. “Anticipatory Compliance with Supreme Court Rulings.” Polity 14: 294-313.

Hansford, Thomas and James Spriggs. 2006. The Politics of Precedent on the U.S. Supreme Court. Princeton: Princeton University Press.

Hilbe, Joseph M. 2011. Negative Binomial Regression. Cambridge: Cambridge University Press.

Kastellec, Jonathan. 2007. "Panel Composition and Judicial Compliance on the US Courts of Appeals." Journal of Law, Economics, and Organization 23: 421-441.

King, Gary. 1989. Unifying Political Methodology. Ann Arbor: University of Michigan Press.

Klein, David. 2002. Making Law in the United States Courts of Appeals. New York: Cambridge University Press.

Martin, Andrew D., and Kevin M. Quinn. 2002. "Dynamic Ideal Point Estimation via Markov Chain Monte Carlo for the U.S. Supreme Court, 1953-1999.” Political Analysis 10: 134153.

McGuire, Kevin, Georg Vanberg, Gregory Caldeira, and Charles Smith. 2009. "Measuring Policy Content on the U.S. Supreme Court." Journal of Politics 71: 1305-1321.

Miceli, Thomas and Metin Cosgel. 1994. "Reputation and judicial decision-making." Journal of Law, Economics and Organization 23: 31-51.

Murphy, Walter F. 1964. Elements of Judicial Strategy. Chicago: University of Chicago Press.

Posner, Richard. 1990. The Problems of Jurisprudence. Cambridge, MA: Harvard University Press.

Posner, Richard. 1993. “What do judges maximize?" Supreme Court Economic Review 3: 1-41.

Posner, Richard. 2008. How Judges Think. Cambridge, MA: Harvard University Press.

Randazzo, Kirk A. "Strategic Anticipation and the Hierarchy of Justice in the U.S. District Courts.” 36 Am. Pol. Res. 669-693 (2008)

Ruckman, P.S. 1993. "The Supreme Court, Critical Nominations, and the Senate Confirmation Process." Journal of Politics 55: 793-805.

Segal, Jeffrey. 1985. "Measuring Change on the Supreme Court: Examining Alternative Models." American Journal of Political Science 29: 461-479. 
Shepard's Citations. 2008. "Checking a Citation: The Shepard's Citations Service." LexisNexis Research Help.

Shipan, Charles and Megan Shannon. "Delaying Justice(s): A Duration Analysis of Supreme Court Confirmations.” American Journal of Political Science 47: 654-668.

Spaeth, Harold. Sara Benesh, Lee Epstein, Andrew D. Martin, Jeffrey A. Segal, and Theodore J. Ruger. 2013. "Supreme Court Database," Version 2013 Release 01. URL: http://supremecourtdatabase.org.

Spriggs II, James F., and Thomas G. Hansford. 2000. "Measuring Legal Change: The Reliability and Validity of Shepard's Citations." Political Research Quarterly 53: 327-341.

Spriggs II, James F., and Thomas G. Hansford. 2001. "Explaining the Overruling of U.S. Supreme Court Precedent.” Journal of Politics 63: 1091-1111.

Westerland, Chad, Jeffrey A. Segal, Lee Epstein, Charles Cameron, and Scott Comparato. 2010. "Strategic Defiance and Compliance in the U.S. Court of Appeals." American Journal of Political Science 54: 891-905.

Zorn, Christopher. 1998. "An Analytic and Empirical Examination of Zero-Inflated and Hurdle Poisson Specifications.” Sociological Methods \& Research 26: 368-400. 


\section{Appendix - Robustness Checks}

This appendix provides estimates from zero-inflated negative binomial models (with standard errors clustered on Supreme Court opinion) as a robustness check on the random effects models reported in the body of the paper. The zero-inflated models do not account for heterogeneity in the dispersion parameter. However, they provide a separate logit model (the "inflation model") to predict whether an observation has no observations, followed by a count model that estimates a negative binomial model for the positive counts. The inflation model is a logit model predicting the probability of observing a zero count. Note the key result: The number of Justices has the expected, statistically significant impact in the count model of both estimations. The more Justices remain, the fewer the number of strong negative treatments, and the greater the number of Followed treatments.

Table A1: Zero-inflated Negative Binomial Model of Strongly Negative Treatments

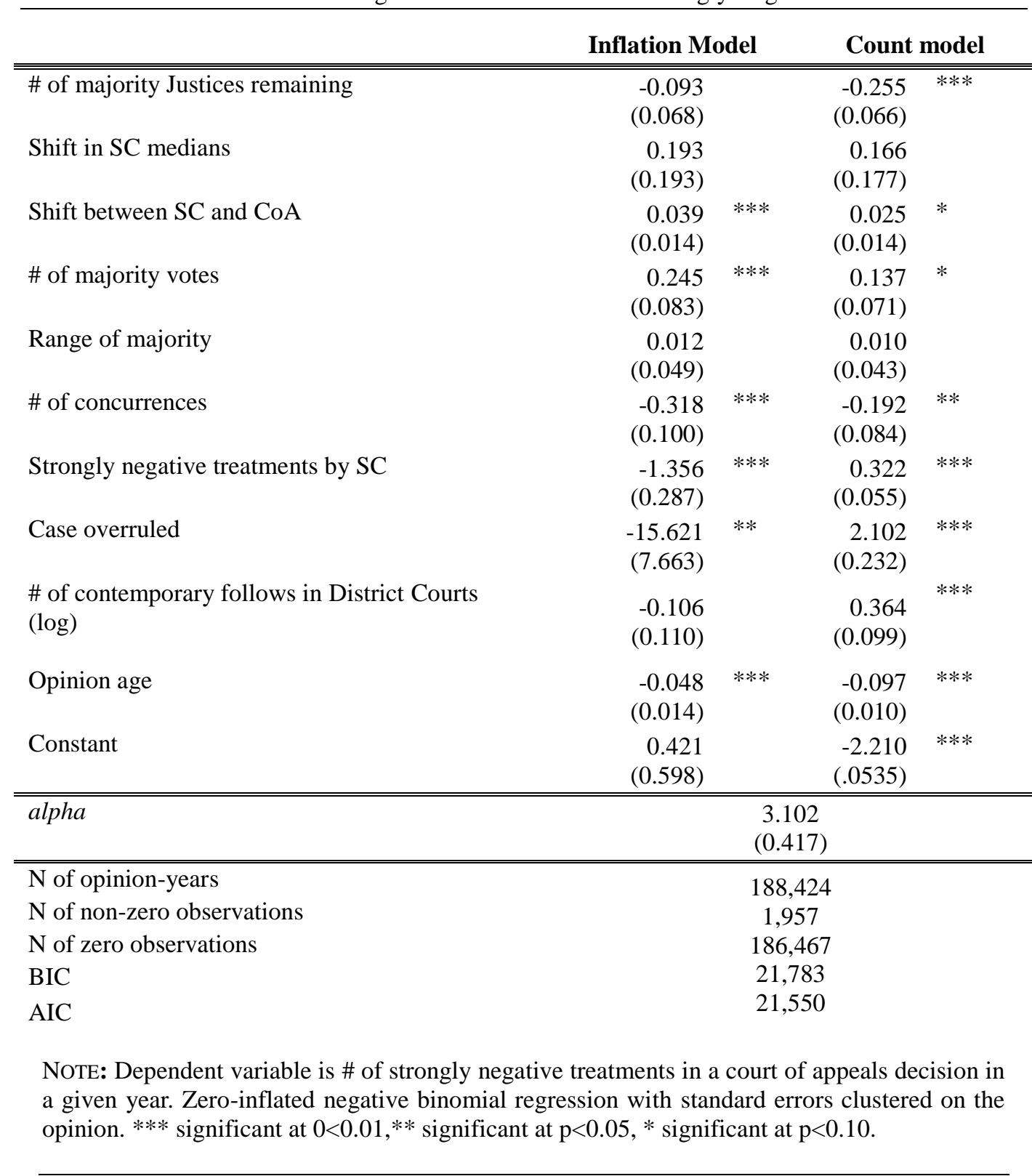


Table A2: Zero-inflated Negative Binomial Model of Follow Treatments

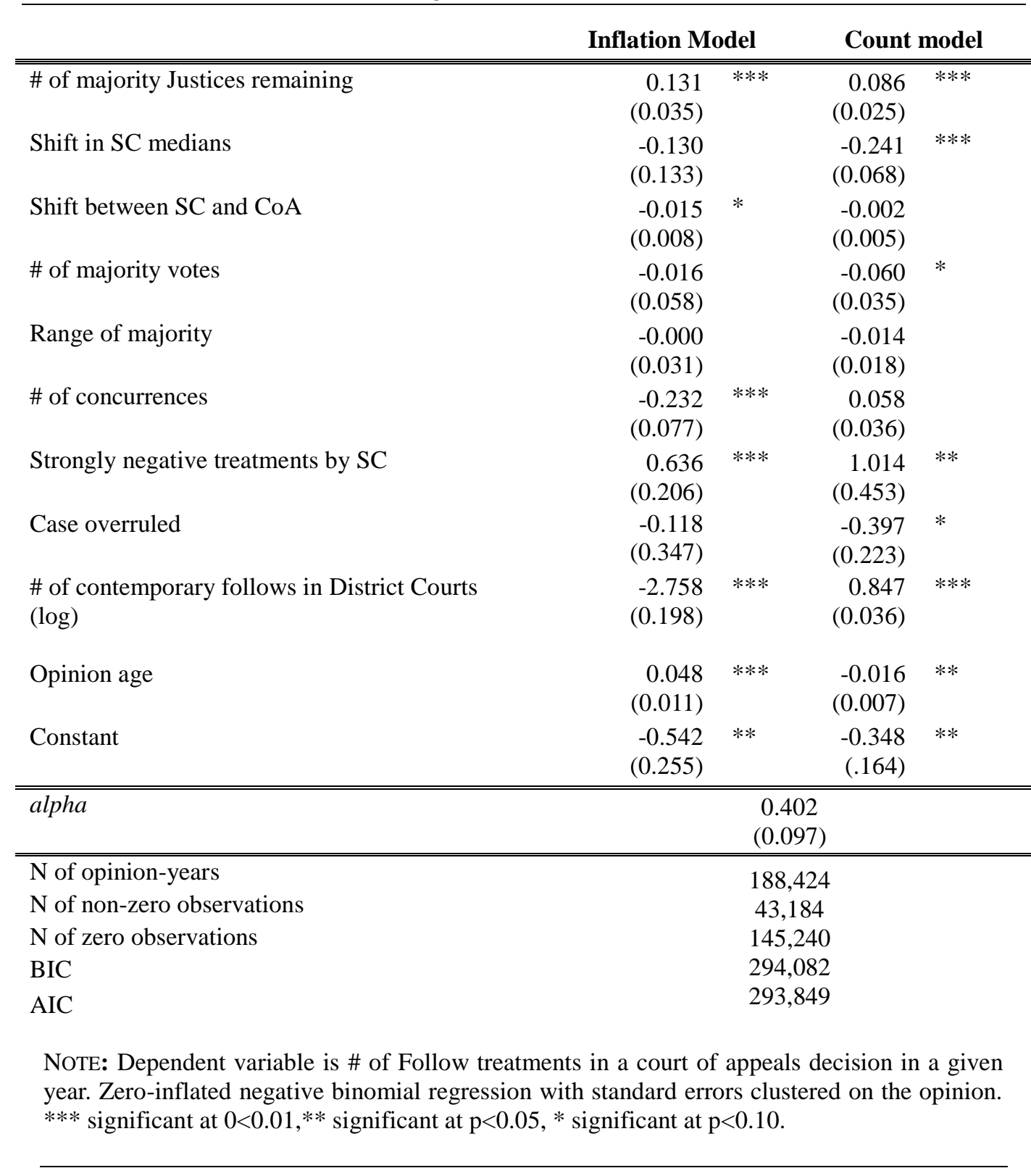

